\title{
Electrophysiological characteristics of supraventricular arrhythmias after cardiac transplantation - a case series
}

\author{
(DIvan Prepolec *, \\ (D) Vedran Pašara, \\ DBorka Pezo-Nikolić, \\ (D)Maja Čikeš, \\ (D)Boško Skorić, \\ (DDavor Puljević, \\ DDavor Miličić, \\ (D) Vedran Velagić
}

University of Zagreb School of Medicine, University Hospital Centre Zagreb, Zagreb, Croatia
KEYWORDS: supraventricular tachycardia, supraventricular arrhythmia, radiofrequency ablation, cardiac transplantation.

CITATION: Cardiol Croat. 2021;16(1-2):13. | https://doi.org/10.15836/ccar2021.13

*ADDRESS FOR CORRESPONDENCE: Ivan Prepolec, Klinički bolnički centar Zagreb, Kišpatićeva 12, HR-10000 Zagreb, Croatia. / Phone: +385-95-8405437 / E-mail: iprepolec@gmail.com

ORCID: Ivan Prepolec, https://orcid.org/0000-0001-5870-202X • Vedran Pašara, https://orcid.org/0000-0002-6587-2315 Borka Pezo-Nikolić, https://orcid.org/0000-0002-0504-5238 • Maja Čikeš, https://orcid.org/0000-0002-4772-5549 Boško Skorić, https://orcid.org/0000-0001-5979-2346 • Davor Puljević, https://orcid.org/0000-0003-3603-2242 Davor Miličić, https://orcid.org/0000-0001-9101-1570 • Vedran Velagić, https://orcid.org/0000-0001-5425-5840

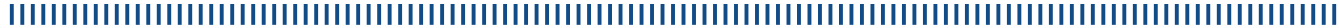

Supraventricular tachycardias (SVT) are increasingly recognized late complications after cardiac transplantation (CTX). The most commonly described arrhythmias include cavotricuspid isthmus (CTI)-dependent atrial flutter (AFL), other macroreentrant atrial tachycardias (MRAT) and focal atrial tachycardias (AT). Although surgical substrate can be important, the effect of the surgical technique on the mechanism and the occurrence of arrhythmia remains unclear. ${ }^{1-3}$ We describe characteristics of CTX patients who presented with SVT for electrophysiological studies (EPS) at our centre from 2017 to 2020. Among 6 patients (mean age $48 \pm 18$ years, 4 of 6 were men), 2 presented during the first year after CTX, while 4 patients presented after a long follow-up (13.3 \pm 2.8 years). Cardiac rejection was ruled out in all patients. In 3 patients significant graft vasculopathy was present. Initially, the conventional EPS was performed in all patients. In 5 cases, the initial diagnosis was CTI-dependent AFL and a successful radiofrequency ablation of CTI was performed. In one case, the arrhythmia was due to the non-CTIdependent MRAT and rate-control strategy was adopted. During the follow-up (29.2 \pm 10.2 months), 3 patients remained without recurrences. In two patients early recurrence was noted (after 1 and 3 months) and a second EPS was performed (conventional or electroanatomical mapping) which demonstrated the multiple MRAT unsuitable for ablation. These patients were managed conservatively while one of them received second CTX due to advanced graft vasculopathy. During the follow-up one patient died due to graft rejection. In our group of patients typical AFL and other non-CTI-dependent MRAT were observed. In CTI-dependent AFL, conventional radiofrequency ablation was effective, while recurrences were more difficult to treat. Extensive scarring of the atria is the substrate for multiple MRAT circles that are not easily amenable with ablation.

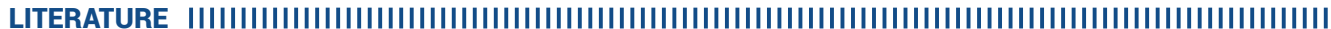

1. Elsik M, Teh A, Ling LH, Virdee M, Parameshwar J, Fynn SP, Kistler PM. Supraventricular arrhythmias late after orthotopic cardiac transplantation: electrocardiographic and electrophysiological characterization and radiofrequency ablation. Europace. 2012 0ct;14(10):1498-505. https://doi.org/10.1093/europace/eus092

2. Renedo MF, González JL, Giunta GA, Giordanino EF, Ameri AS, Mysuta MA, Ramirez DA, Favaloro LE, Favaloro RR, Absi D0, Galizio N0, Bertolotti AM. Radiofrequency ablation of supraventricular arrhythmias after orthotopic heart transplantation: Long-term follow-up of a single-center experience. Clin Transplant. 2020 Nov 23:e14165. https://doi.org/10.1111/ctr.14165

3. Mouhoub Y, Laredo M, Varnous S, Leprince P, Waintraub X, Gandjbakhch E, et al. Catheter ablation of organized atrial arrhythmias in orthotopic heart transplantation. J Heart Lung Transplant. 2017 Jul 21:S1053-2498(17)31924-1. https://doi.org/10.1016/j.healun.2017.07.022 